\title{
David Oliver: Blaming hospitals for systemwide problems will make winter bleaker
}

\author{
David Oliver consultant in geriatrics and acute general medicine
}

Berkshire

Our increasing inability to meet the four hour target for emergency departments has been used as a surrogate for all the NHS's ills. Stories of overcrowding, long waits on trolleys, and ambulances stacking up outside make the headlines week after week. But there have been lamentably few informed discussions in the media of the complex underlying systemic causes behind the pressures at the hospital front door.

Last week a Department of Health spokesperson said that "we have robust plans for winter," in response to the Labour Party's call for an urgent $£ 500 \mathrm{~m}$ cash injection. ${ }^{2}$ We can all keep calm and carry on, then?

Dangerously full hospitals, struggling to cope with demand they can't control, are no longer just for winter but a year round phenomenon. ${ }^{34}$ But fears of "winter pressures" get everyone talking in autumn. Politicians fear bad headlines and the electorate's reaction. National health system leaders in bodies that may not be as "arm's length" as statute suggests feel that heat and transmit it down to hospital boards. The boards may in turn put pressure on frontline clinical teams, who are already running to stand still.

It is right to insist that acute care hospitals do everything possible to improve patient flow, refine internal processes, minimise delays, and collaborate with local partners. And there is excellent best practice guidance from NHS Improvement to back them up. ${ }^{5}$ How well hospitals implement such guidance varies, as does their use of scarce hospital beds. But it is wrong to hold hospital leaders and teams solely to account for problems beyond their doors and not in their gift to solve.

Yet it was reported last month that chief executives of acute trusts had been summoned to NHS headquarters to be browbeaten over winter and emergency department waits and overcrowding. Some of these senior leaders were reportedly forced to group chant an undignified "we can do this," pledging to improve their performance. ${ }^{6}$ Personal accounts of the meeting were of an intimidating atmosphere and a focus on "tackling behaviours by the consultant body." There were also reports of resignations as a result of political pressure on hospital chief executives the week before the meeting. ${ }^{7}$ Such coercive approaches have long been discredited in healthcare, but we still default to them. ${ }^{8}$

Not long after this now notorious meeting the Care Quality Commission's new inspector of hospitals, Ted Baker, gave an interview in which he spoke much welcome good sense about our historical failure to invest in community and primary care services and the consequent pressure on acute hospitals. ${ }^{910}$

Last week a King's Fund report concluded that the NHS has among the lowest per capita bed numbers and fullest hospitals in the developed world, having cut capacity as fast as admissions have risen. Hospitals running so close to $100 \%$ occupancy cannot optimise patient flow or maintain the flexibility to cope with small surges in demand. ${ }^{11}$

Meanwhile, social care provision has been savagely cut since $2010,{ }^{12}$ access to intermediate care services outside hospitals is insufficient and worsening, ${ }^{13}$ delayed transfers of care of patients stranded in hospital have risen exponentially, ${ }^{14}$ and there is a huge workforce and workload crisis in general practice and community nursing. ${ }^{15}{ }^{16}$ Numbers of patients arriving at the hospital front door are still rising. ${ }^{4}$

Even in NHS England's admirable "new models of care" vanguards, the rise in admissions has continued-just a bit more slowly than in control sites. ${ }^{17}$ And we have growing gaps in the hospital workforce, not least in emergency and acute medicine and nursing. We won't solve any of these issues in time for Christmas, and there is no magic workforce tree on which to spend Labour's proposed funding boost.

Putting all responsibility onto hospital leaders and staff is understandable. But that doesn't make it right.

Competing interests: See www.bmj.com/about-bmj/freelancecontributors/david-oliver.

Provenance and peer review: Commissioned; not externally peer reviewed.

Follow David on Twitter: @mancunianmedic

BBC News. Labour's Jon Ashworth calls for £500m NHS winter bailout. Sep 2017. www. bbc.co.uk/news/uk-politics-41397682. 
2 lacobucci G. Labour calls for $£ 500 \mathrm{~m}$ winter bailout fund to ease NHS pressure. BMJ 2017;359:j4466. doi:10.1136/bmj.j4466 pmid:28954737.

3 NHS England. A\&E attendances and emergency admissions. https://www.england.nhs. $\mathrm{uk} /$ statistics/statistical-work-areas/ae-waiting-times-and-activity.

4 King's Fund. What's going on in A\&E? The key questions answered. https://www.kingsfund. org.uk/projects/urgent-emergency-care/urgent-and-emergency-care-mythbusters.

5 NHS Improvement. Good practice guide: focus on improving patient flow. https:// improvement.nhs.uk/resources/good-practice-guide-focus-on-improving-patient-flow.

6 Lintern S, Clover B, Williams D. NHS leaders chant "we can do this" at A\&E improvement summit. HSJ Sep 2017. https://www.hsj.co.uk/workforce/nhs-leaders-chant-we-can-dothis-at-aande-improvement-summit/7020633.article.

7 Williams D, Clover B. Resignations send stark warning to chief execs on A\&E performance. HSJ Sep 2017. https://www.hsj.co.uk/acute-care/resignations-send-stark-warning-to-chiefexecs-on-aande-performance/7020575.article.

8 Kline R. The NHS cannot afford to ignore bullying any longer. Guardian. Aug 2016. https: //www.theguardian.com/healthcare-network/2016/aug/16/the-nhs-cannot-afford-to-ignorebullying-any-longer.

9 Donnelly L. NHS is not fit for the 21st century, hospital chief inspector warns. Telegraph. Sep 2017. www.telegraph.co.uk/news/2017/09/29/nhs-not-fit-21st-century-hospital-chiefinspector-warns.
10 NHS not fit for the 21st century, says chief inspector of hospitals. Guardian. Sep 2017. https://amp.theguardian.com/society/2017/sep/30/nhs-not-fit-for-the-21st-century-sayschief-inspector-of-hospitals.

11 Ewbank L. Hospital bed numbers: can the downward trend continue? King's Fund. Sep 2017. https://www.kingsfund.org.uk/blog/2017/09/hospital-bed-numbers.

12 King's Fund. Social care for older people: home truths. Sep 2016. https://www.kingsfund. org.uk/publications/social-care-older-people.

13 Oliver D. David Oliver: Improving access to intermediate care. BMJ 2017;359:i6763. doi: 10.1136/bmj. 6763 pmid:28057619

14 National Audit Office. Discharging older patients from hospital. May 2016. https://www. nao.org.uk/report/discharging-older-patients-from-hospital.

15 Baird B. Is general practice in crisis? big election questions. King's Fund. Jun 2017. https: /www.kingsfund.org.uk/publications/articles/big-election-questions-gp-crisis.

16 King's Fund. Quality of district nursing care under threat. Sep 2016. https://www.kingsfund. org.uk/press/press-releases/district-nursing-crisis.

17 Oliver D. David Oliver: Reducing acute admissions-a timely reality check. BMJ 2017;359:j2082. doi:10.1136/bmj.j2082 pmid:28487315.

Published by the BMJ Publishing Group Limited. For permission to use (where not already granted under a licence) please go to http://group.bmj.com/group/rights-licensing/ permissions 